Article

\title{
BiodiverSO: A Case Study of Integrated Project to Preserve the Biodiversity of Vegetable Crops in Puglia (Southern Italy)
}

\author{
Massimiliano Renna ${ }^{1,2}$, Francesco F. Montesano ${ }^{2, *}$, Angelo Signore ${ }^{1, *}$ (D), Maria Gonnella ${ }^{2}$ \\ and Pietro Santamaria 1 (iD) \\ 1 Department of Agricultural and Environmental Science, University of Bari Aldo Moro, \\ Via Amendola 165/A, Bari, Italy; massimiliano.renna@uniba.it (M.R.); pietro.santamaria@uniba.it (P.S.) \\ 2 Institute of Sciences of Food Production (ISPA), CNR, Via Amendola 122/O, Bari, Italy; \\ maria.gonnella@ispa.cnr.it \\ * Correspondence: francesco.montesano@ispa.cnr.it (F.F.M.); angelo.signore@uniba.it (A.S.); \\ Tel.: +39-080-544-3098
}

Received: 29 June 2018; Accepted: 16 August 2018; Published: 18 August 2018

\begin{abstract}
Puglia region is particularly rich in agro-biodiversity, representing an example of how local vegetables varieties can still strongly interact with modern horticulture. Unfortunately, the genetic diversity of vegetable crops in this region has been eroded, due to several factors such as abandonment of rural areas, ageing of the farming population, and failure to pass information down the generations. This article summarizes the objectives, methodological approach and results of the project "Biodiversity of the Puglia's vegetable crops (BiodiverSO)", an integrated project funded by Puglia Region Administration under the 2007-2013 and 2014-2020 Rural Development Program (RDP). Results were reported for each of the eight activities of the project. Moreover, the Polignano carrot (a local variety of Daucus carota L.) was described as a case study, since several tasks have been performed within all eight project activities with the aim of verifying the effectiveness of these actions in terms of safeguarding for this genetic resource strongly linked with local traditions. BiodiverSO is an example of protection and recovery of vegetables at risk of genetic erosion that could help to identify and valorize much of the Puglia's plant germplasm.
\end{abstract}

Keywords: characterization; conservation; databases; genetic resources; history; local varieties; recovery; sanitation; seed bank

\section{Introduction}

The concepts of biodiversity, of its progressive loss and the need to protect it, are now rooted in the scientific and policy maker communities. These concepts are also increasingly gaining popularity with ordinary people. According to a survey on attitudes of Europeans toward biodiversity, at least eight out of ten Europeans consider the various effects of biodiversity loss to be serious. However, although the majority of Europeans have heard of the term "biodiversity" (60\%), less than one third $(30 \%)$ know what it means, most do not feel informed about biodiversity loss (66\%), and think the EU should better inform citizens about the importance of biodiversity (93\%) [1].

In the general framework of biodiversity issue, which is in most cases referred to natural ecosystems, the concept of "agro-biodiversity" is arising lively interest. According to the FAO definition [2], agro-biodiversity is a vital sub-set of biodiversity, and refers to the diversity in agro-ecosystems. It comprises the diversity of living organisms and genetic resources (cultivated species, varieties, and breeds; wild flora; soil microorganisms; predators; and pollinators). Agro-biodiversity is the result of interaction among the environment, genetic resources and 
management systems and practices, encompassing the variety and variability that are necessary for sustaining food production and food security. Therefore, local knowledge and culture can be considered as integral parts of agro-biodiversity, because the human activity of agriculture shapes and conserves this biodiversity.

Intensive agriculture has generally resulted in higher productivity, but also in a trend towards decreasing levels of agro-biodiversity. It has been noted that the so called "green revolution" in agriculture, with its modern scientific approaches to plant breeding, represented a biodiversity narrowing phase, by replacing genetically diverse landraces and local varieties (selected over centuries and representing an incredible heritage of diversity) with uniform varieties such as hybrid F1 in vegetables [3,4]. As reported by some authors [5], "a local variety (also called: landrace, farmer's variety, folk variety) is a population of seed- or vegetative-propagated crop characterized by greater or lesser genetic variation, which is however well identifiable and which usually has a local name ... has not been subjected to an organized program of genetic improvement ... is characterized by a specific adaptation to the environmental and cultivation conditions of the area where it has been selected ... is closely associated with the traditions, the knowledge, the habits, the dialects and the occurrences of the human population that have developed it and/or continue its cultivation". During the last century, almost $75 \%$ of local varieties have been lost, but this percentage may rise to $90 \%$ in USA. Modern varieties are conceived to meet the requirements of market, processing industry and modern distribution. At the same time, they are subjected to rapid obsolescence.

The preservation of agro-biodiversity represents a key-point to assure adaptability and resilience of agro-ecosystems to the global challenge we will be facing in the near future to produce more and better food in a sustainable way. However, many components of agro-biodiversity would not survive without human interference. On the other hand, human choices may represent a threat for the agro-biodiversity preservation.

Puglia region is located in the southeastern part of Italy. It is largely open to the Adriatic and Ionian seas with a coastal zone of nearly $800 \mathrm{~km}$. The area of about $19,360 \mathrm{~km}^{2}$ shows more than $60 \%$ of territory below $200 \mathrm{~m}$ above sea level, with some peaks of more than $1000 \mathrm{~m}$ located in the northeast and northwest. Puglia has a typically Mediterranean climate with temperatures that may fall below $0{ }^{\circ} \mathrm{C}$ in winter (in the northern part or hills) and exceed $40{ }^{\circ} \mathrm{C}$ in summer. Annual rainfall ranges between 400 and $550 \mathrm{~mm}$, mostly concentrated during the winter.

Due to its climatic conditions and land characteristics, Puglia is one of the most important regions in Italy for the vegetable production, accounting for $\approx 21 \%(\approx 92,000 \mathrm{ha})$ and $\approx 24 \%(\approx 3,261,000$ tons $)$ of the total open air growing area and the amount of vegetables produced at national level, respectively [6]. The region is among the leaders for the production of several vegetable crops such as broccoli and cauliflower, celery, parsley, processing tomato, artichoke, endive and escarole, cabbage, fennel, lettuce, cucumber, early potato and asparagus. The vegetable production industry accounts for about $30 \%$ of the total economic value of the regional agricultural sector. About 8000 ha of the regional vegetable growing area are interested by organic cultivation systems, representing the $30 \%$ of the total national organic vegetable cultivation [7].

At the same time, at national level, the predominant position of Puglia in terms of vegetable production industry does not overlap at all with its position in the seed industry (less than $2 \%$ of commercial vegetable varieties registered in the national register are from companies located in the region). However, Puglia represents an example of how local vegetable varieties can still strongly interact with modern horticulture in the definition of a complex food system, in which local culture and traditions are interconnected with local productions and local environment. In fact, the region is particularly rich in local varieties of vegetables. Some of them are still largely used and requested by the population.

Unfortunately, the genetic diversity of vegetable crops in the Puglia region has been eroded, due to several factors such as abandonment of rural areas, ageing of the farming population, and failure to pass information down the generations (leading to loss of knowledge and historical memory), which can 
vary in relation to the type of genetic resource and location [8,9]. Moreover, loss of family vegetable gardens near settlements, as a consequence of intense urban development, has led to a considerable loss of agro-biodiversity, especially among folk varieties grown for family consumption [4].

For these reasons, the Puglia Region Administration planned two specific actions under the 2007-2013 and 2014-2020 Rural Development Programme (RDP) to preserve regional genetic biodiversity. "Protection of biodiversity" provides financial support for a five-year period for seed savers committed to preserving in situ the plant genetic resources listed in a specific annex of the RDP, while "Integrated projects and regional biodiversity system" funds the salvage of native plant genetic resources and knowledge of ethno-botany. The overall goal is to create a biodiversity network to promote the exchange of information between stakeholders to facilitate the diffusion and protection of genetic resources in agriculture.

This article aims to pointing out objectives, methodological approach and results of the project "Biodiversity of the Puglia's vegetable crops (BiodiverSO)", one of the five integrated project funded by Puglia Region Administration under RDP.

\section{Methodology}

BiodiverSO (https:/ / biodiversitapuglia.it/) is a collaborative project funded within the RDP of the Puglia Region Administration on the topic "Diffusion and protection of genetic resources in agriculture". The 48-month project started in April 2013 involving fourteen partners (https: //biodiversitapuglia.it/partner/) from academia, research institutions, public consortia and private companies from different disciplines (genetic, agriculture, biology, biotechnology, chemistry, biochemistry, plant science and engineering). The project was coordinated by the Department of Agricultural and Environmental Science, University of Bari Aldo Moro.

According to the aims of BiodiverSO, project activities were organized and scheduled as eight different Work Packages regarding the local varieties of vegetables in Puglia.

WP 1-History. This activity consisted in acquiring information on local genetic resources, through an accurate bibliographic and territorial investigation work. The aim was to retrieve the history, provenance, distribution on the territory, knowledge and traditions related to cultivation and use of local varieties.

WP 2-Recovery. The recovery activity was based on research and subsequent collection of propagation material of the local varieties present in the Puglia territory. Seeds or other propagation material were taken from the field, with the relevant information on the cultivation technique, uses of the products and local traditions.

WP 3 Ex situ conservation. This activity involved the conservation, outside the natural environment (ex situ), of seeds and/or plant parts suitable for multiplication, sowing and/or planting, revitalization, propagation and management of the material, to ensure the use of germplasm, safeguard varieties at risk of genetic extinction and attempt a subsequent reintroduction.

WP 4-Characterization. This activity aimed to assess genetic, agronomic, morphological, quantitative and nutritional traits of the recovered genetic resources by using several tools and techniques.

WP 5-Sanitation and registration in national catalogs. The first aim of this activity was to obtain protocols for producing virus-free genetic resources for conservation, breeding, and production. Moreover, the registration of local varieties and related products in the "List of Traditional Agri-Food Products" (LTAFP) of the Italian Department for Agriculture was carried out.

WP 6-Databases. All information and results obtained through each project activity were cataloged and used to create inventories regarding sampling sites and data on the recovered genetic resources.

WP 7-Data sheets writing. This activity was carried out for each genetic resource with the aim to create standardized systems of identification, characterization and recognition of local varieties. 
WP 8-In situ conservation. In situ conservation of the recovered propagation material was carried out through reproduction and cultivation, in isolation and in conditions of maximum purity, within local farms.

\section{Obtained Results and Discussion}

\subsection{Project's General Results}

\subsubsection{WP 1-History}

The information obtained from bibliographic and territorial investigations allowed obtaining a multimedia library that collects, makes accessible and available the knowledge acquired on local genetic resources (https://biodiversitapuglia.it/biblioteca/?idt=1). Thanks to this activity, 243 documents were recovered (Figure 1). Moreover, interviews, videos, (https:/ / biodiversitapuglia.it/biblioteca/ ?idt=4) geo-referenced photos and 125 thematic maps (https:/ / biodiversitapuglia.it/biblioteca/?idt=6) were produced.

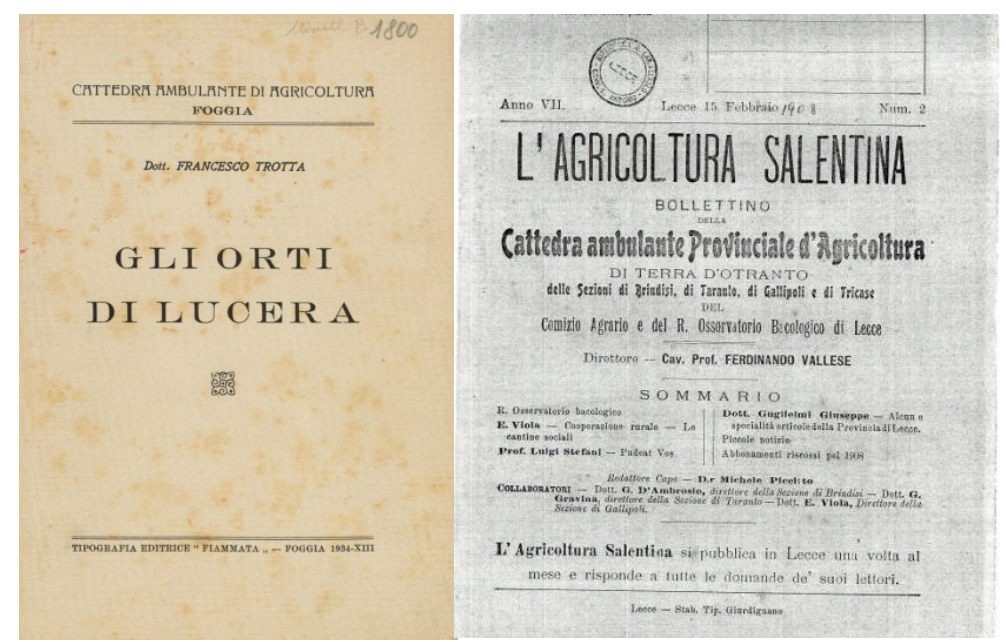

Figure 1. Examples of ancient documents recovered under the bibliographic research activity.

Very interesting information on local varieties was recovered during this activity. For example, the "Lucera artichoke", a landrace of Cynara cardunculus L. subsp. scolymus Hayek, has been cultivated for decades by local smallholder farmers in Capitanata (Puglia, Italy) around the town of Lucera (Foggia). Its flower heads have an ovoid shape, while the color of the external bracts is green with purple nuance. The length is about $10 \mathrm{~cm}$, the diameter $7.5-8.5 \mathrm{~cm}$ and the weight ranges $150-180 \mathrm{~g}$ (Figure 2).

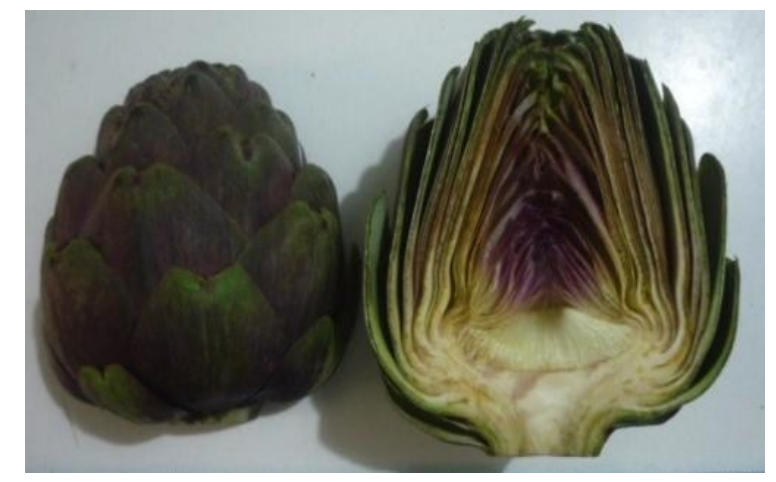

Figure 2. A typical flower head of the "Lucera artichoke". 
At the beginning of the 1900s, this landrace of artichoke was cultivated in many family gardens in the urban surroundings of Lucera. Unfortunately, these areas have been affected by intense building activity that has irreversibly subtracted fields traditionally used for horticulture. This has determined a considerable reduction of the "Lucera artichoke" production as well as a loss of knowledge and historical memory, and today this landrace is grown In only a few home gardens by some old farmers.

The historical importance of the "Lucera artichoke" is due to the presence of the Saracens in Puglia during the 12th century. In effect, Egidi [10] reported that a colony of Saracens was transferred into Lucera city between 1224 and 1225 A.C. by King Federico II of Svevia. Furthermore, investigations on historical texts have been carried out about Saracens customs during ancient times in Puglia. Findings indicate that the cultivation of kinaria (artichoke) was practiced by the Saracens in Southern Italy at least since the 12th century. Thus, it is possible that the cultivation of the artichoke began at least two centuries before with respect to what is generally reported in several publications dealing with horticulture. In this context, further study could be carried out with the aim to verify if the kinaria cultivated by Saracens in Capitanata during ancient times represents a possible ancestor of the "Lucera artichoke" landrace.

\subsubsection{WP 2-Recovery}

Several companies, farmers or simple enthusiasts that conserve and cultivate local vegetable varieties at risk of genetic erosion were identified. Seeds (Figure 3) or other propagation material have been taken from the field together to relevant information on the cultivation technique, uses of the products and local traditions. In addition, geographic and topographical information on the cultivation areas of local varieties have been acquired. Thanks to this activity, about 350 companies have been visited, over 530 accessions have been recovered and the relative descriptive sheets have been prepared. The very important role of home gardens as repositories of agro-diversity has been well verified. Home gardens, whether found in rural or peri-urban areas, are characterized by a structural complexity and multi-functionality which enables the provision of different benefits to ecosystems and people. At the same time, home gardens are important social and cultural spaces where knowledge related to agricultural practices is transmitted. Therefore, it is very important to promote their role in the conservation of vegetables crops and cultural heritage.

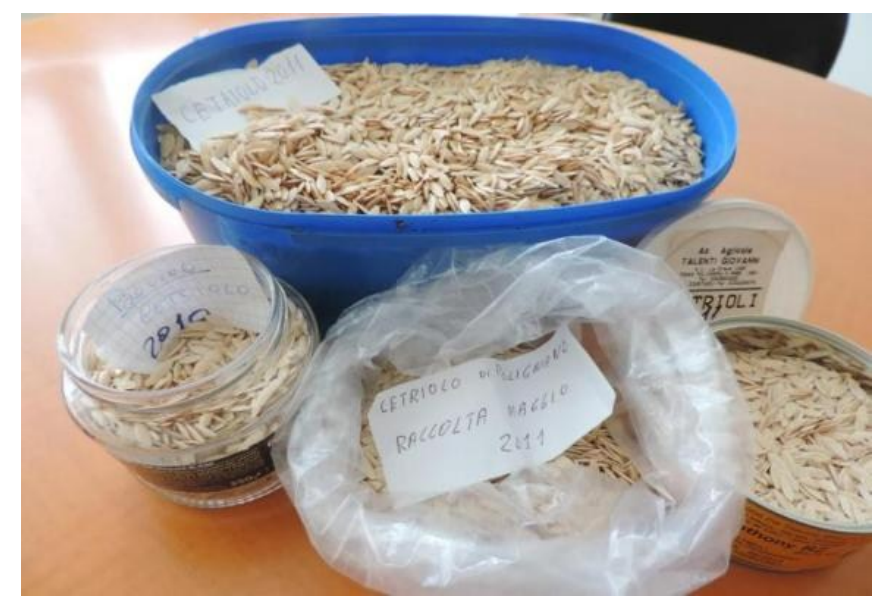

Figure 3. Example of accessions seeds recovered from farmers or simple enthusiasts during the WP2 activity (Photo credit: Beniamino Leoni).

\subsubsection{WP 3-Ex Situ Conservation}

Ex situ conservation of the recovered propagation material was carried out through the creation and management of catalog fields within experimental farms (Figure 4), long-time seeds preservation 
in seed banks (Figure 5) as well as the maintenance of propagation material by in vitro and/or slow-growing techniques (Figure 6), aimed to keep the agamic propagation material in good conditions, reducing conservation costs and space.
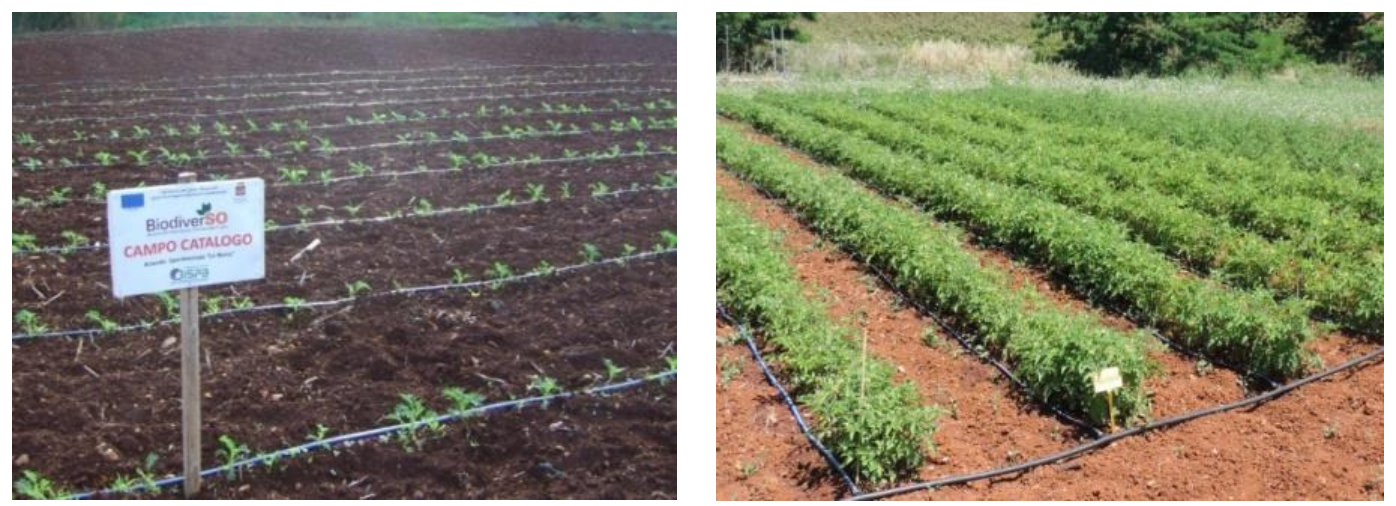

Figure 4. Catalog fields of Brassicaeae (left) and different local varieties of Solanum lycopersicum L. (right) within "La Noria" experimental farm of the National Research Council, Bari, Italy.
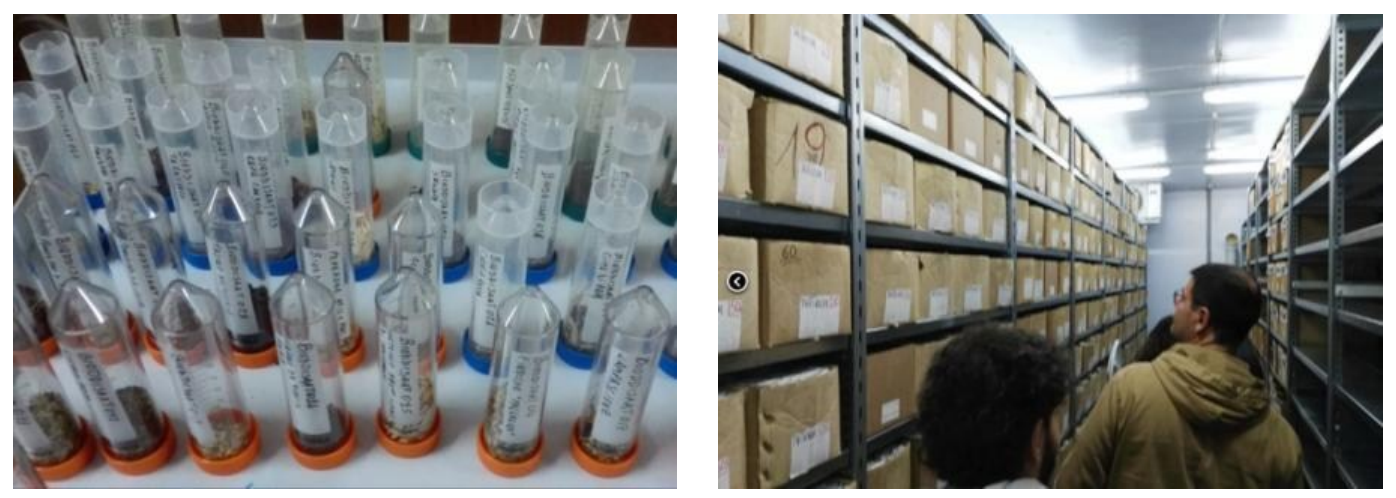

Figure 5. Example of accessions seeds (left) recovered to be preserved at the seed bank (right) of the Institute of Biosciences and Bioresources of the Italian National Research Council in Bari, Italy (Photo credit: Beniamino Leoni).

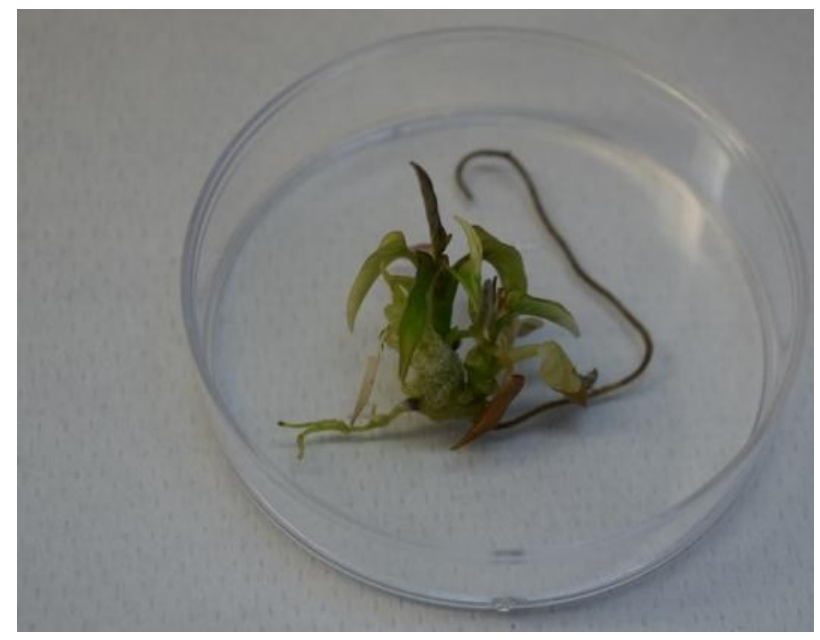

Figure 6. Shoots of Ipomoea batatas L. after 12 months of in vitro slow-growing (Photo credit: Claudia Ruta-from https:/ / biodiversitapuglia.it). 


\subsubsection{WP 4-Characterization}

Several local varieties and wild edible plants (a total of 141 genotypes) were characterized for morphological, chemical (including qualitative and nutritional) and genetic traits (Table 1).

Table 1. Genetic resources studied during the project activity (adapted from Accogli et al. [11]). For each one, performed activities are indicated by using $\mathrm{X}$ symbol or a specific acronym. Registration column reports the state of art regarding Puglia local varieties with Protected Geographical Indication or registered as an item in the List of "Traditional Agri-Food Products" of the Italian Department for Agriculture.

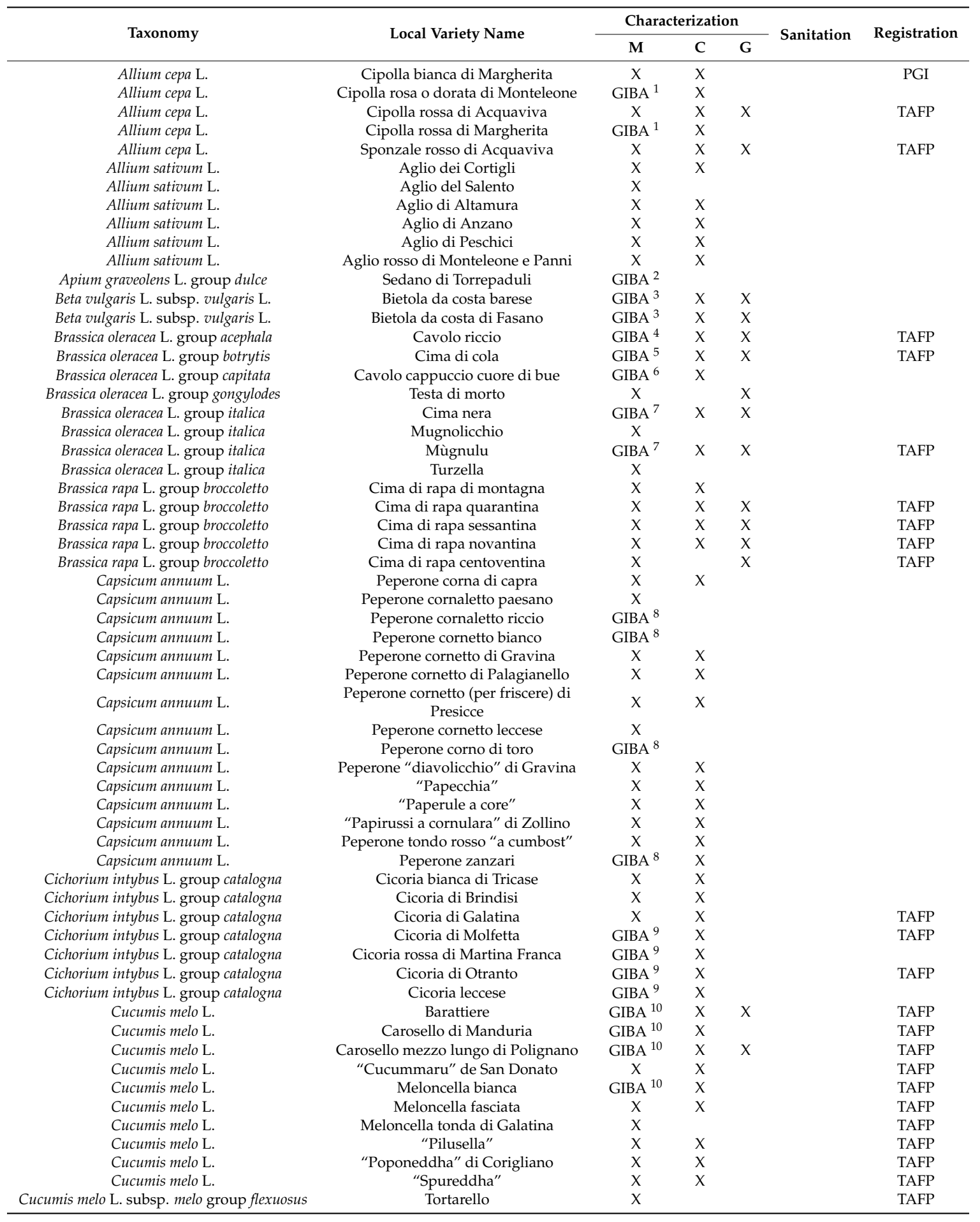


Table 1. Cont.

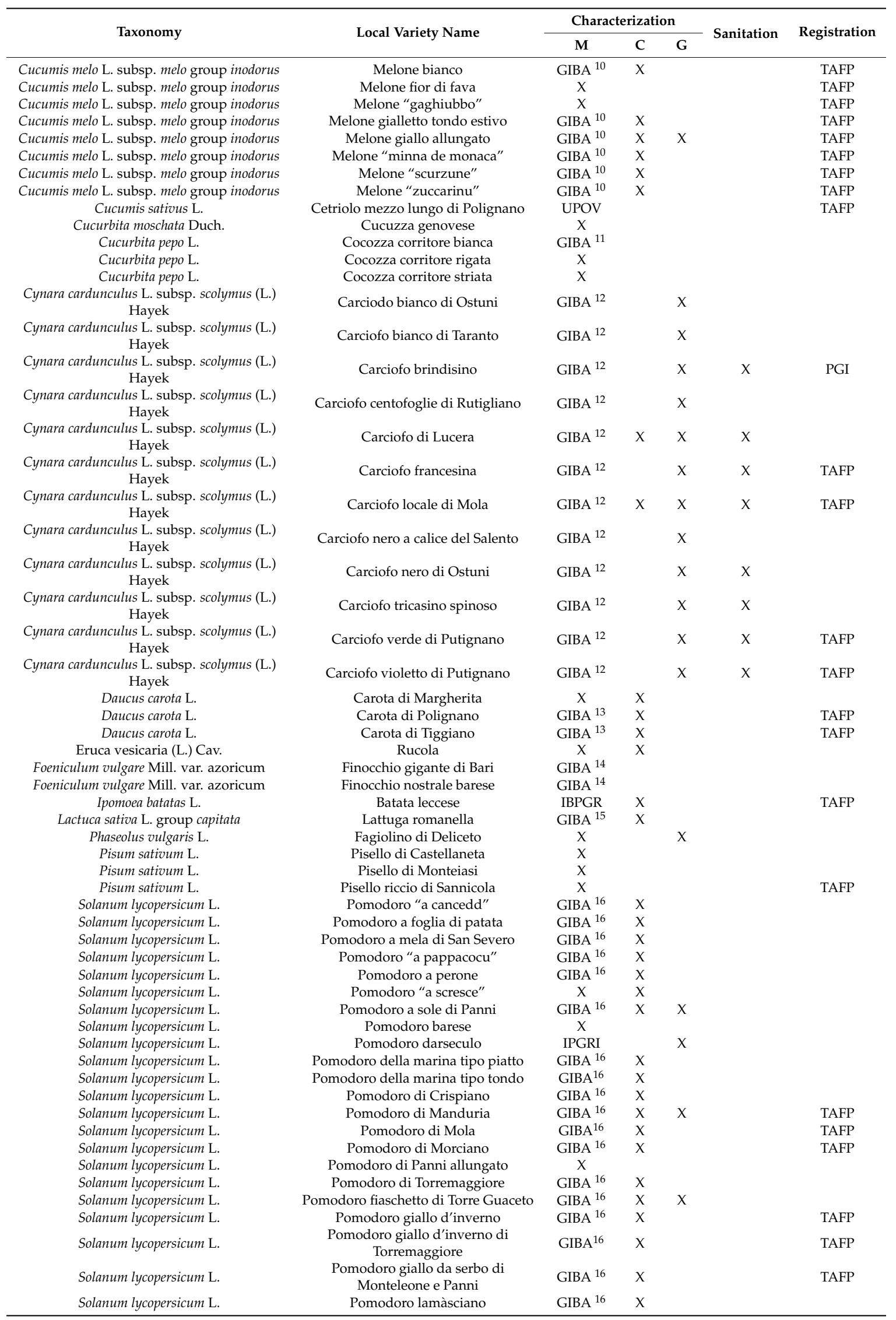


Table 1. Cont.

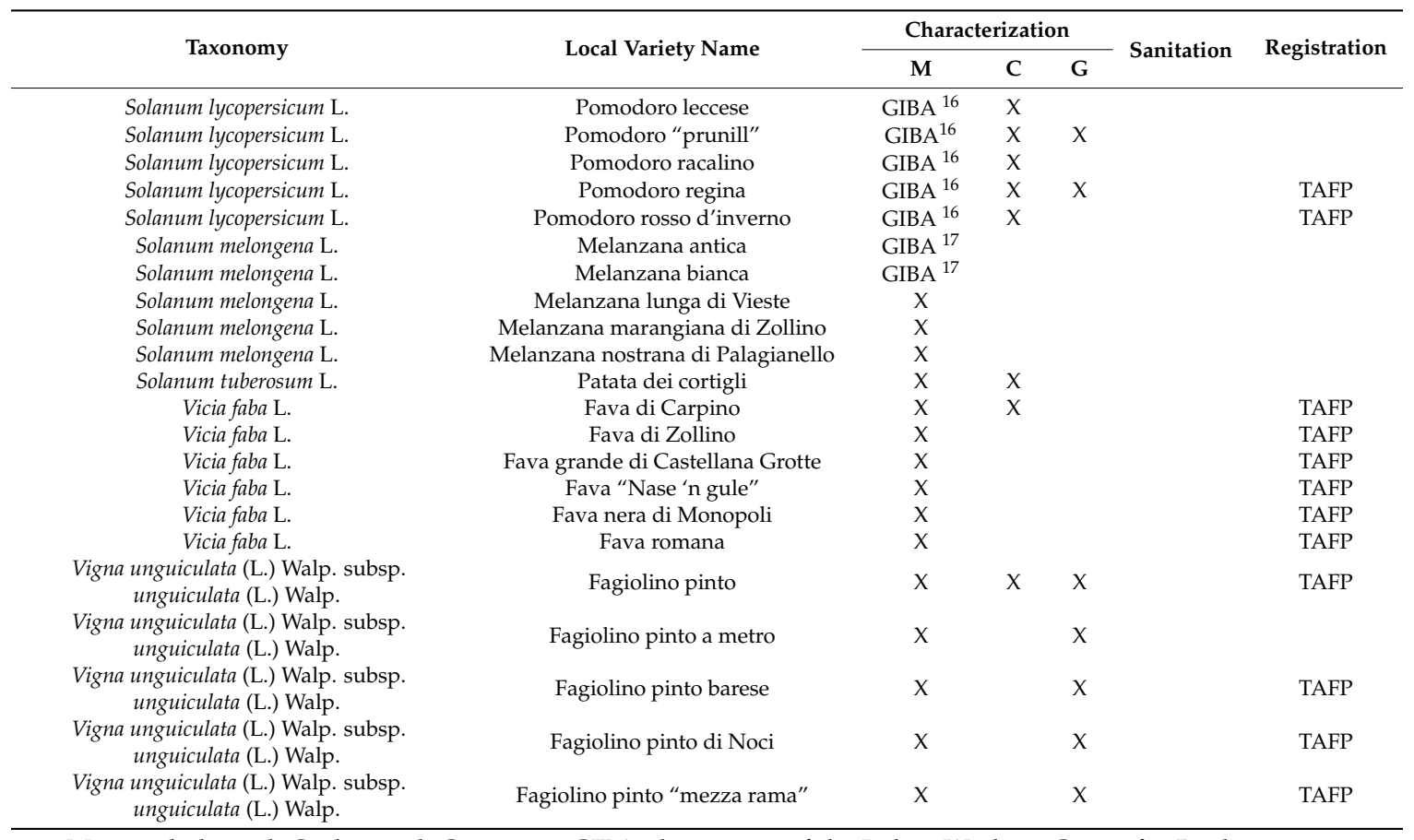

M, morphological; C, chemical; G, genetic; GIBA, descriptors of the Italian Working Group for Biodiversity in Agriculture; TAFP, List of "Traditional Agri-Food Products" of the Italian Department for Agriculture; PGI, Protected Geographical Indication within European Community; UPOV, descriptors of the Union for the Protection of New Varieties of Plants; IBPGR, descriptors of the International Board for Plant Genetic Resources; IPGRI, descriptors of the International Plant Genetic Resources Institute; CPVO, Community Plant Variety Office; ${ }^{1}$ Ref. CPVO TP $/ 46 / 2 ;{ }^{2}$ Ref. CPVO TP $/ 82 / 1 ;{ }^{3}$ Ref. UPOV TG $/ 106 / 4 ;{ }^{4}$ Ref. UPOV TG $/ 90 / 6 ;{ }^{5}$ Ref. CPVO TP $/ 45 / 2 ;{ }^{6}$ Ref. CPVO TP $/ 48 / 2$; ${ }^{7}$ Ref. CPVO TP $/ 151 / 2 ;{ }^{8}$ Ref. CPVO TP $/ 76 / 2 ;{ }^{9}$ Ref. UPOV TG $/ 154 / 3 ;{ }^{10}$ Ref. CPVO TP $/ 104 / 2 ;{ }^{11}$ Ref. CPVO TP $/ 119 / 1 ;{ }^{12}$ Ref. CPVO TP $/ 184 / 1 ;{ }^{13}$ Ref. CPVO TP $/ 49 / 3 ;{ }^{14}$ Ref. CPVO TP $/ 183 / 1 ;{ }^{15}$ Ref. CPVO TP $/ 13 / 4 ;{ }^{16}$ Ref. CPVO TP $/ 44 / 3 ;{ }^{17}$ Ref. CPVO TP $/ 117 / 1$.

This activity allowed also to obtain original results published in the international scientific literature and/or exploitable for future research (Table 2).

Table 2. Literature published targeting the different local varieties studied during project activities.

\begin{tabular}{cc}
\hline Local Variety & References \\
\hline Barattiere & Pavan et al. [12] \\
tata leccese & Ruta and Lambardi [13] \\
Carciofo bianco di Taranto & Spanò et al. [14] \\
Carciofo brindisino & Curci et al. [15] \\
Carciofo cento foglie di Rutigliano & Ruta e Lambardi [12] \\
Carciofo di Lucera & Renna et al. [16] \\
Carciofo francesina & Spanò et al. [14] \\
Carciofo locale di Mola & Renna et al. [16] \\
Carciofo verde di Putignano & Spanò et al. [14] \\
Carciofo violetto di Putignano & Spanò et al. [14] \\
Carosello di Manduria & Spanò et al. [14] \\
& Pavan et al. [12] \\
Carota di Polignano & Cefola et al. [17,18] \\
& Renna et al. [19] \\
Carota di Tiggiano & Signore et al. [20] \\
Cicoria di Galatina & Scarano et al. [21] \\
& Renna et al. [22] \\
Cicoria di Molfetta & Testone et al. [23] \\
Melone giallo allungato & Renna et al. [22] \\
Melone "minna de monaca" & Testone et al. [23] \\
Melone "scurzune" & Girelli et al. [24] \\
Pomodoro di Manduria & Girelli et al. [24] \\
& Girelli et al. [24] \\
& Spanò et al. [25] \\
\hline & \\
\hline &
\end{tabular}


For example, Pavan et al. [12] used genotyping-by-sequencing (GBS) to characterize patterns of genetic diversity and genomic features within Cucumis melo L. Analyses of genetic structure, principal components, and hierarchical clustering supported the identification of three distinct subpopulations. One of them includes accessions of the local variety Carosello, referable to the chate taxonomic group. This is one of the oldest domesticated forms of C. melo, once widespread in Europe and now exposed to the risk of genetic erosion. The second subpopulation contains landraces of Barattiere, a regional vegetable production that had never been characterized at the DNA level and that was previously erroneously considered another form of chate melon. The third subpopulation includes genotypes of winter melon (C. melo var. inodorus). Genetic analysis within each subpopulation revealed patterns of diversity associated with fruit phenotype and geographical origin. In a study aimed to present the complete chloroplast genome sequence of the globe artichoke, obtained by a combination of data retrieved from genome and BAC clone sequencing, genomic DNA was extracted from young leaves of local variety Brindisino [15].

As regards qualitative and nutritional traits, compositional analysis and antioxidant properties were carried out for both Polignano and Tiggiano carrots, two colored landraces of Daucus carota L. The local varieties Molfettese and Galatina belong to the Catalogna chicory cultivated group (Cichorium intybus L.) and produce stems consumed at early growth stage as fresh or processed vegetables. These elongating inflorescence stems (so-called "puntarelle" that means small shoot tips) are consumed as fresh, fresh-cut (e.g., sliced into strips and bagged) or fully processed (e.g., cooked and glass jarred, or frozen) vegetables as ready-to eat foods [4,22]. In a context of request for product quality standards and uniformity, Molfettese and Galatina chicories were characterized for some nutritive and quality traits as both fresh and ready-to-use products [22]. These local varieties, used both raw and cooked, represent a refined and nutritious vegetables, because of the presence of several healthy compounds as well as their low nitrate content $[22,23,26]$.

In Puglia some plant parts of vegetables, conventionally considered as by-products, are traditionally used as "unconventional" vegetables. For example, offshoots (so-called cardoni or carducci) of globe artichoke, produced during the vegetative growing cycle and removed by common cultural procedures (Figure 7), are consumed in the same way of cultivated cardoons (Cynara cardunculus L. var. altilis DC).

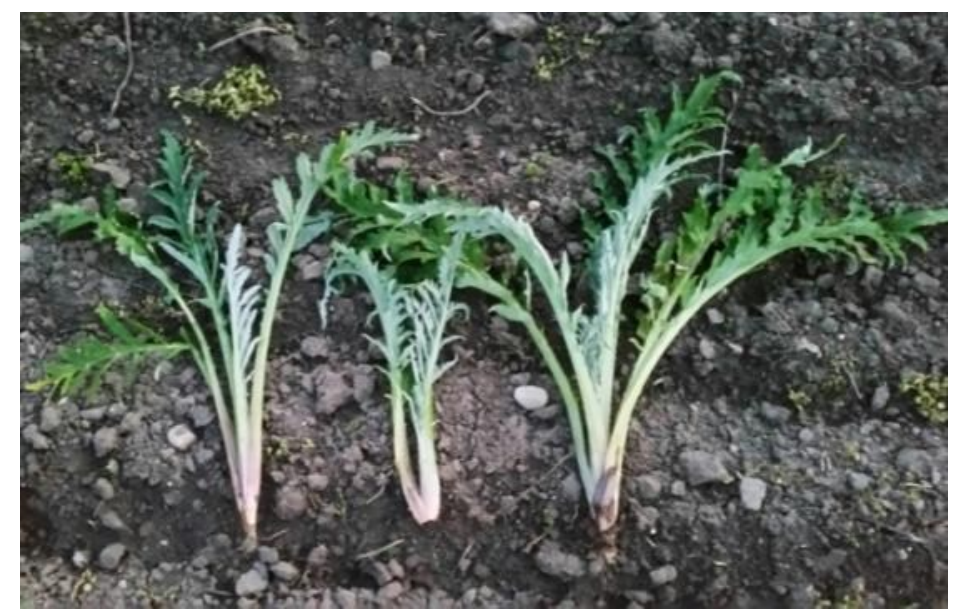

Figure 7. Offshoots (so-called cardoni or carducci) of a globe artichoke landrace.

The stems, petioles, flowers and smaller leaves of summer squash are used as greens (so-called cime di zucchini) (Figure 8), similar to other leafy vegetables such as chicory (C. intybus L.) and Swiss chard (Beta vulgaris L.). 


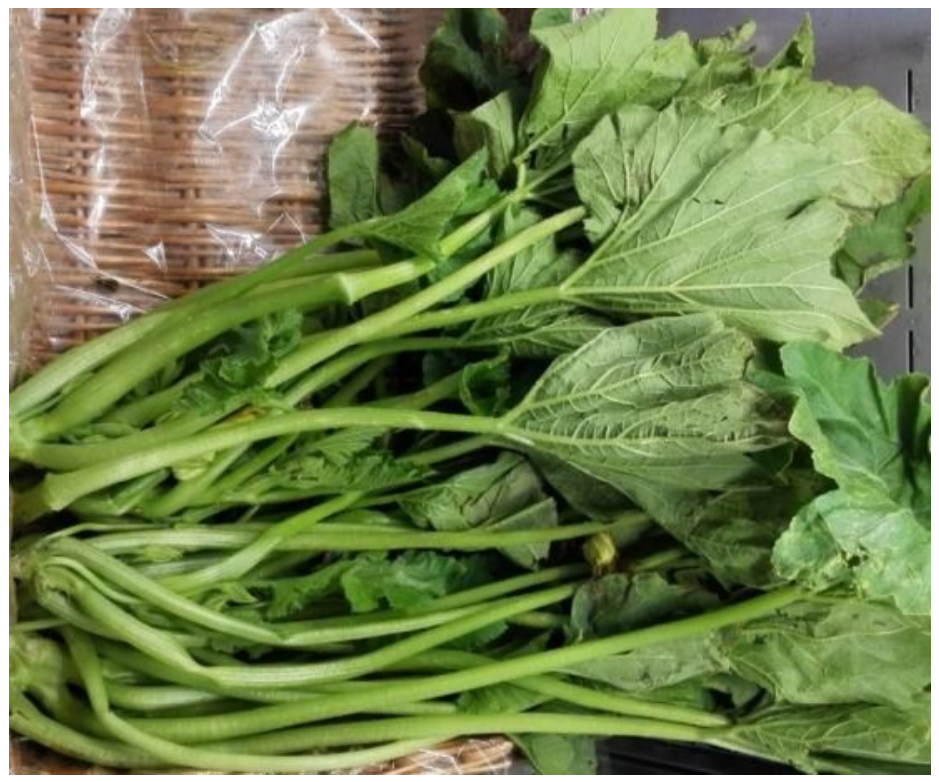

Figure 8. Summer squash greens (so-called cime di zucchini).

In addition, the plant apex of faba bean, about $5-10 \mathrm{~cm}$ long, obtained from the green pruning, are used as greens (so-called cime di fava) (Figure 9) such as spinach leaves (Spinacia oleracea L.).

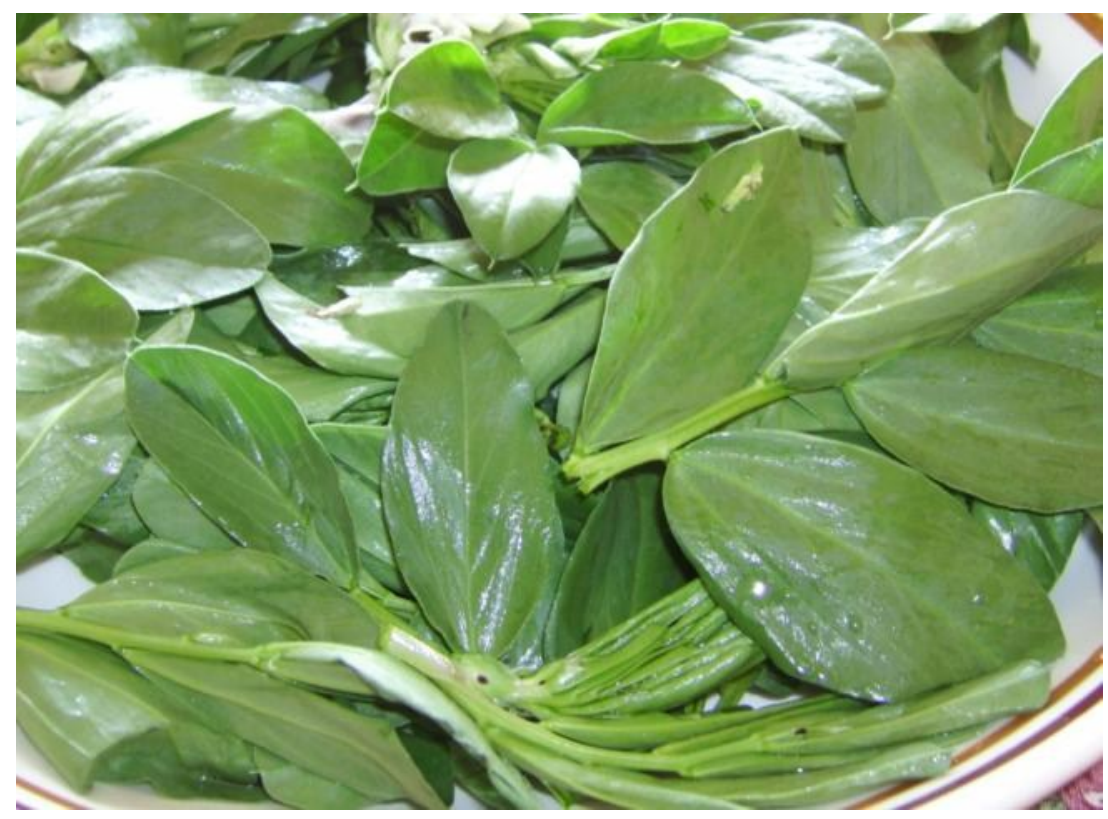

Figure 9. Faba greens (so-called cime di fava).

Renna et al. [16] showed that offshoots of globe artichoke, summer squash greens and faba greens have good potential as novel foods, being nutritious and refined products. In fact, for their content of fiber, offshoots of globe artichokes can be considered a useful food to bowel. Summer squash greens could be recommended as a vegetable to use especially in the case of hypoglycemic diets considering both content and composition of their carbohydrates. For their low content of nitrate, faba greens can be recommended as a substitute of nitrate-rich leafy vegetables.

A particular segment of Puglia's agro-biodiversity is represented by wild edible plants (WEP), which includes some progenitors of cultivated vegetables with which there is a continuum in the 
genetic profile [4]. WEP are a favorite delicacy in many countries and represent an extraordinary source of essential elements for the human health. They may be used to diversify and enrich modern diet with many colors and flavors, playing an important role in the diet of inhabitants in different parts of the world [27]. In Puglia, the harvesting of WEP is a time-honored custom and several species represent the essential ingredient to prepare some traditional food [28]. Renna et al. [27] determined thirteen elements $(\mathrm{Na}, \mathrm{K}, \mathrm{Ca}, \mathrm{Mg}, \mathrm{Fe}, \mathrm{Mn}, \mathrm{Cu}, \mathrm{Zn}, \mathrm{Cr}, \mathrm{Co}, \mathrm{Cd}, \mathrm{Ni}$ and $\mathrm{Pb}$ ) in 11 different WEP (Amaranthus retroflexus, Foeniculum vulgare, Cichorium intybus, Glebionis coronaria, Sonchus spp., Borago officinalis, Diplotaxis tenuifolia, Sinapis arvensis, Papaver rhoeas, Plantago lagopus and Portulaca oleracea) collected from countryside and urban areas of Bari. According to these authors, Renna [29] indicated that WEP may give a substantial contribution to the intake of mineral elements by consumers, representing a potentially good source in the daily diet.

Crenate broomrape (Orobanche crenata Forssk.) is a parasitic plant, which can cause serious damage to the production of legume crops in much of the Mediterranean basin. However, some authors [30] have reported its use as a food or folk drug, suggesting that it could be a refined food (Figure 10) with interesting nutritional traits. Thanks to WP 4 activity, Renna et al. [16] demonstrated that crenate broomrape may be considered as a very low source of dietary sodium as well as a vegetable with a low-middle content of nitrate. However, crenate broomrape showed a very interesting antioxidant activity, since a $100 \mathrm{~g}$ serving size supplies about $27 \mathrm{mMol}$ of Trolox Equivalent [16].

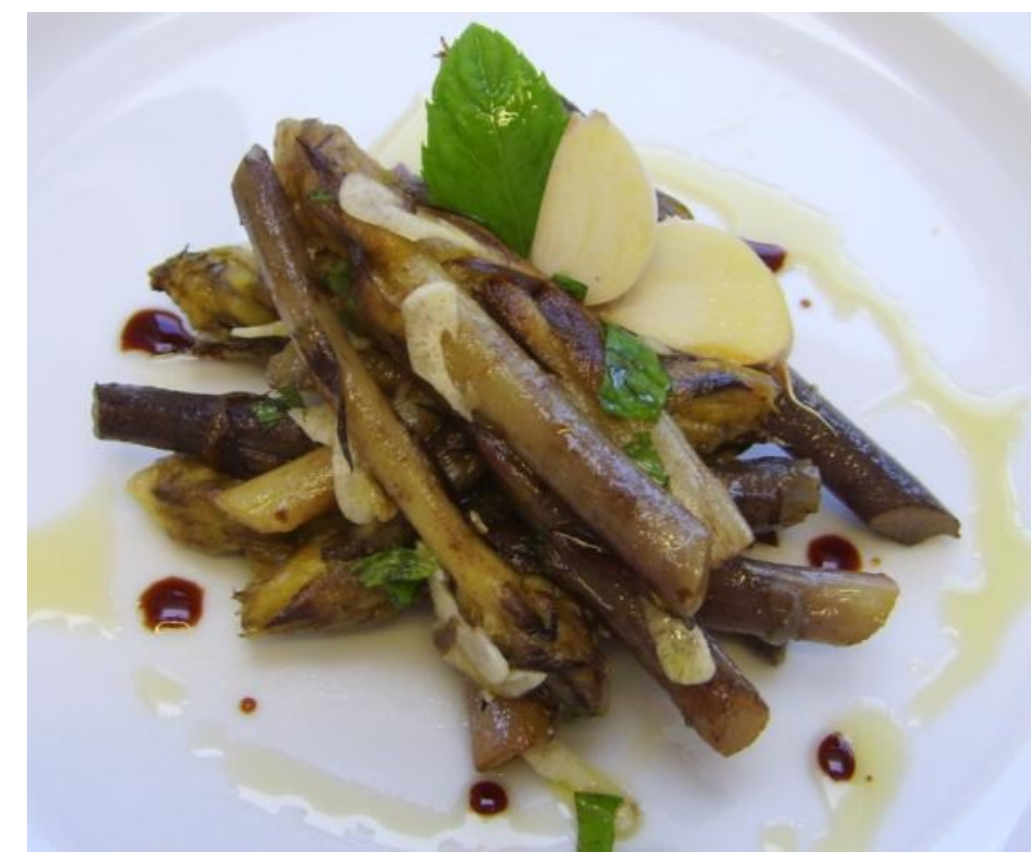

Figure 10. Salad of crenate broomrape.

Sea fennel (Crithmum maritimum L.) is a perennial halophyte species typical of coastal ecosystems (Figure 11) used as a fresh ingredient for many food preparations [31]. It is listed as an item in the LTAFP of Puglia by the Italian Department for Agriculture. 


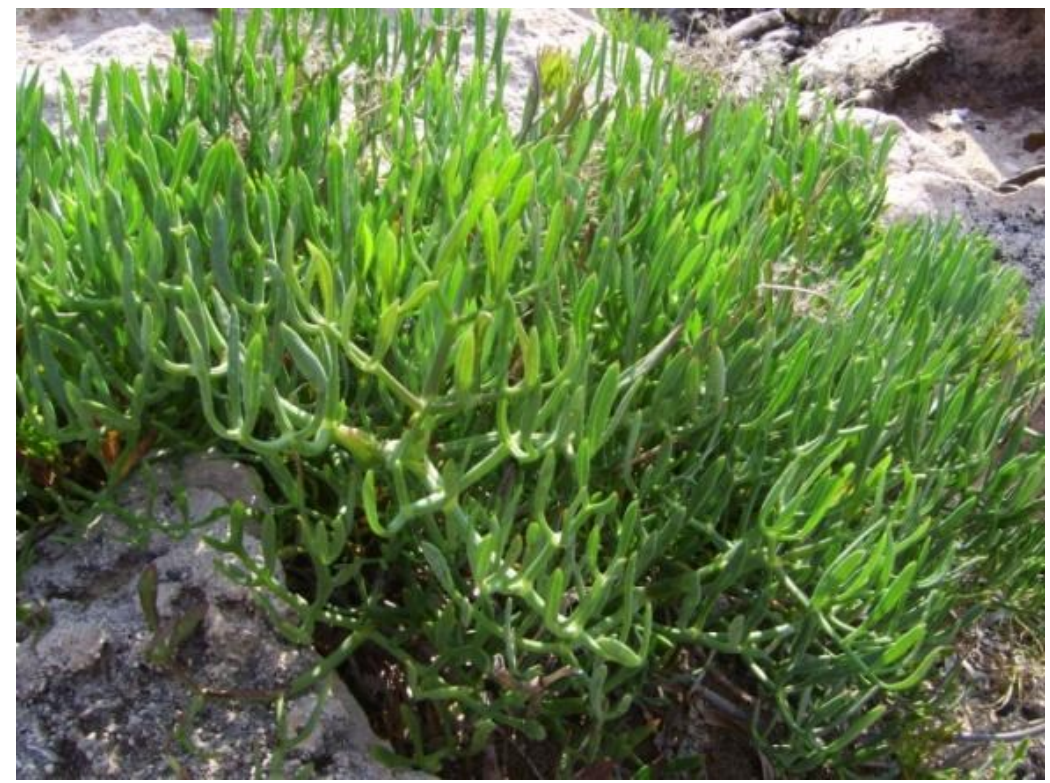

Figure 11. Plant of sea fennel on a rock-sandy beach as typical example of natural habitat for this halophyte.

Nevertheless, although considered as a promising biosaline crop, this halophyte is underutilized for commercial cultivation possibly due to a shortage of its consumer demand. Being also an aromatic herb, sea fennel plants may be used not only as fresh product but also as dried herbs. Thus, sea fennel has been characterized for some nutritive and quality traits as both fresh and dried product $[32,33]$. Based on these considerations, the possibility to cultivate the sea fennel is under consideration [34].

\subsubsection{WP 5-Sanitation and Registration in the LTAFP}

In Puglia, many globe artichoke ecotypes remained neglected and unnoticed for a long time and were progressively eroded by several causes, which include a poor phytosanitary status. Thanks to this activity a protocol for producing virus-free artichoke genetic resources for conservation, breeding, and production was carried out [14]. Eight local varieties of globe artichoke (Table 1) were sanitized from artichoke Italian latent virus (AILV), artichoke latent virus (ArLV) and tomato infectious chlorosis virus (TICV) by meristem-tip culture and in vitro thermotherapy through a limited number of subcultures to reduce the risk of "pastel variants" induction of and loss of earliness. A total of 25 virus-free primary sources were obtained and conserved ex situ in a nursery. It is expected that the use of these sanitized materials supplied by nursery-certified stocks and cultivated in open field for no more than two years should decrease inoculum potential and will ensure genetic resources for conservation, breeding and production [14].

As regards the registration of local varieties and related products in the List of "Traditional Agri-Food Products" (TAFP) of the Italian Department for Agriculture, 34 new registrations were carried out including fresh and processed vegetable products. In this regard, it is important to underline that, for all new registrations, it must be demonstrated that processing, preservation and ageing methods are consolidated in time and harmonious according to traditional rules, for a period of not less than 25 years. Thus, thanks to the accurate bibliographic and territorial investigation work of the WP 1 , it was possible to acquire this essential information. Table 1 reports the state of art regarding Puglia local varieties with Protected Geographical Indication or registered as an item in the List of "Traditional Agri-Food Products" of the Italian Department for Agriculture. 


\subsubsection{WP 6-Database}

Thanks to this activity, a computerized database called BiodiverSO Management System (BMS) was achieved. BMS allows to have a tool for correct and immediate management and processing of data of each project activity.

The dissemination of knowledge about (agro)biodiversity is a strategic factor in communicating the urgent need to defend and protect biological diversity. Thus, sharing and dissemination of the many collected information was promoted through the Project's WEB site (www.biodiversitapuglia. it), to which users access both to obtain information and report new local varieties (https:// biodiversitapuglia.it/segnala-una-varietaspecie/). The Web GIS (https://biodiversitapuglia.it/ webgis.php), with the cartographic collections, and the App for smartphones and tablets complete the usability of the information. Moreover, also social media, such as Facebook (https:/ / www.facebook. com/BiodiverSO) and YouTube (https:/ / www.youtube.com/user/BiodiversitaPuglia), were used for better sharing collected knowledge.

The interest in using informatic tools for collecting information on agro-biodiversity is increasing, since they greatly facilitate the collection and sharing of data. Anyway, in some cases, the use of such tools is not of immediate comprehension for a common user, for example, for the use of APIs, so an effort should be done to simplify these tools and allow greater participation for general public. In this optic, during this activity, we tested two tools freely available, namely Open Data Kit and Google Fusion Tables, to verify if their integrated use would allow a participative collection (and sharing) of data related to agro-biodiversity. Open Data Kit was used to collect information regarding several vegetable crops at risk of genetic erosion. This information, including multimedia and GPS data, were stored into the Google App Engine platform and afterwards was transferred into Google Fusion Tables for mapping and sharing with the general public. Both tools were tested in real scenarios in the Italian region of Puglia and the results seem to be encouraging: Open Data Kit has provided a good platform for the collection of data and it is reliable for georeferencing the fields, while Google Fusion Tables allowed us to show the data and share them in an easy way [35].

Within this activity, the use of Wikipedia was also proposed as a dissemination tool to show how to add/modify articles in Wikipedia for online divulgation and to demonstrate its validity by analyzing some data (pageviews, editing history, and the impact of Wikipedia as a referral toward the project's institutional website) related to the Wikipedia articles that were added/modified. Referrals from Wikipedia increased the visits to the institutional website by $30 \%$, whereas the bounce rate decreased by $15 \%$. Wikipedia may be a good tool to improve the dissemination of knowledge about (agro)biodiversity either online or offline, and the addition in Wikipedia's pages of scientific journal references and links to the projects' website may strengthen the diffusion of scientific knowledge [36].

\subsubsection{WP 7-Data Sheets Writing}

For all recovered local varieties, a descriptive sheet was realized and shared for users (https: // biodiversitapuglia.it/varieta-orticole/). Moreover, with the aim to create a standardized system of identification, other data sheets (Figure 12) were realized by using descriptors from International Plant Genetic Resources Institute (IPGRI), International Union for the Protection of New Varieties of Plants (UPOV), International Board for Plant Genetic Resources (IBPGR) and Community Plant Variety Office (CPVO). Finally, genetic and nutritional data sheets were also realized by using results obtained from the WP 4 activity. 

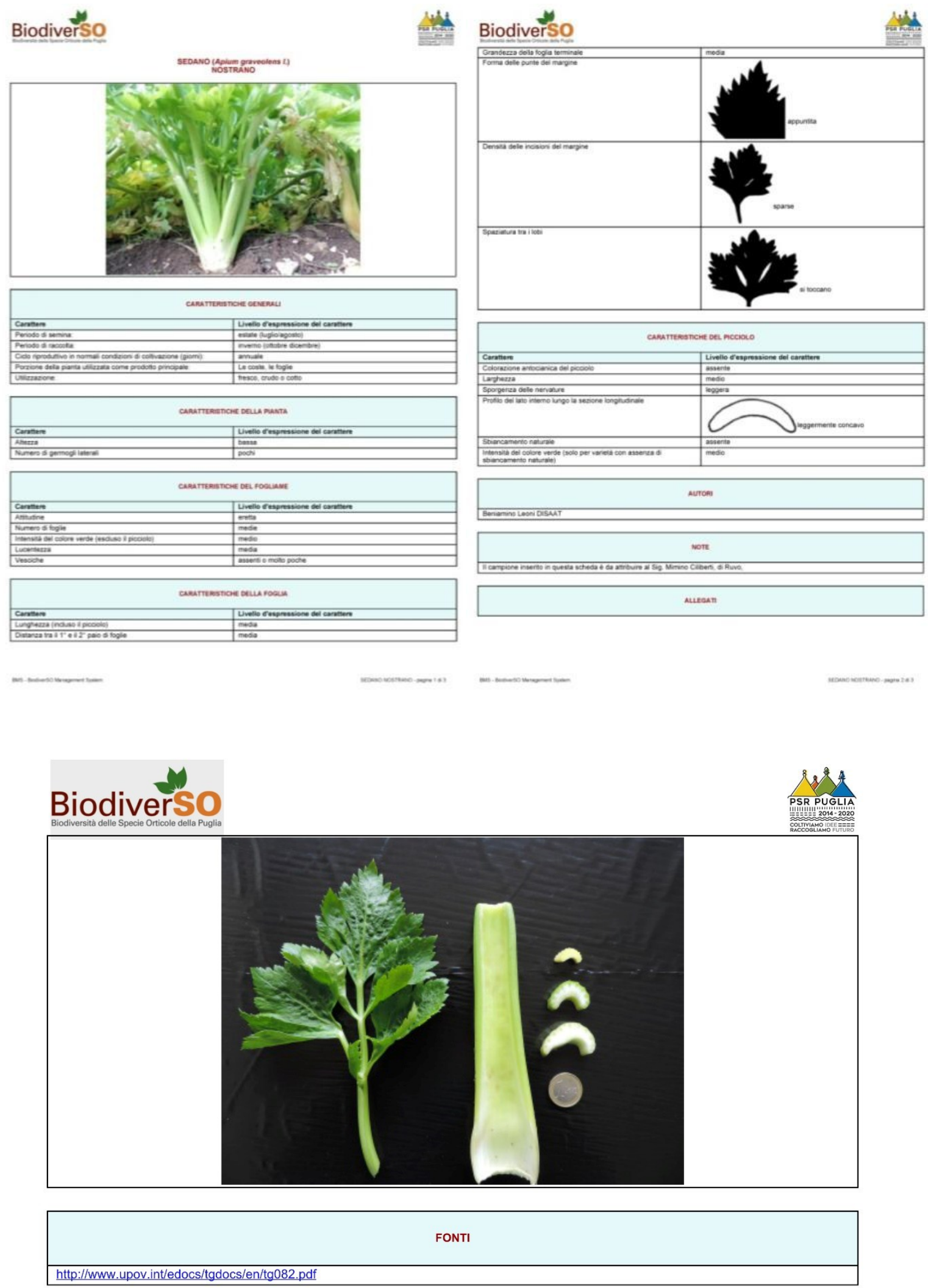

Figure 12. Examples of data sheets realized by using UPOV descriptors for a local variety of Apium graveolens $\mathrm{L}$. 


\subsubsection{WP 8-In situ Conservation}

As a result of this activity, 22 farms were funded for the in situ reproduction and cultivation. The financial support was provided for a five-year period to the so-called seed savers committed to in situ preserving the plant genetic resources. Moreover, some landraces and old open-pollinated varieties of vegetables have been kept alive within communities without any financial support by old farmers who act as seed savers (Figure 13).

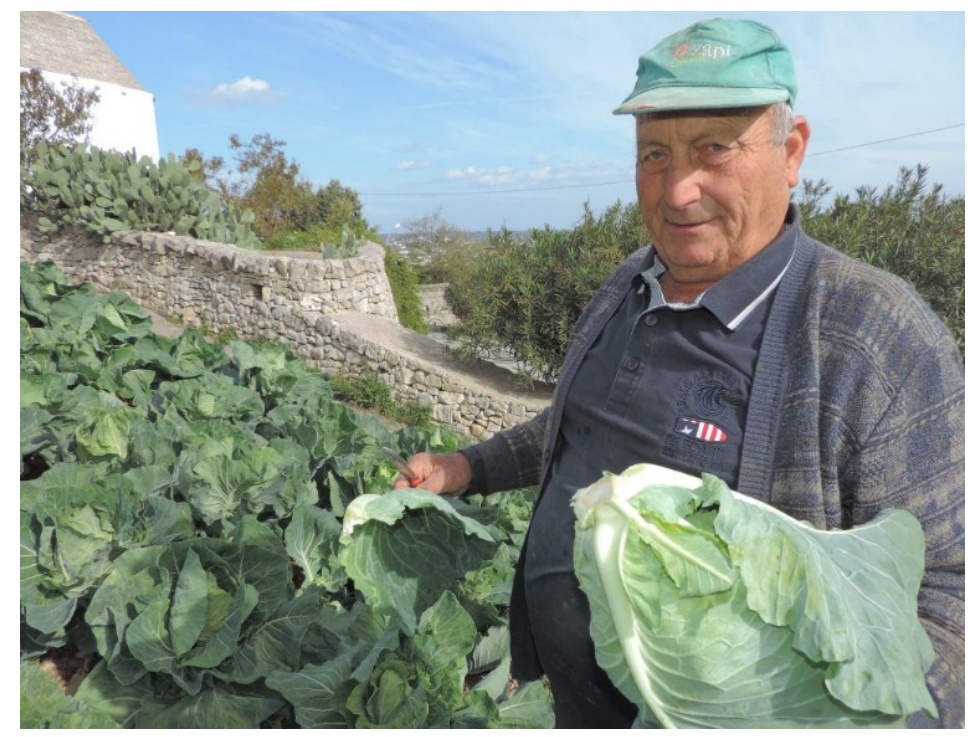

Figure 13. An example of old farmer (Raffaele Cristoforo) who acts as a seed saver of the "Verza a cuore di bue", a local variety of cabbage (Brassica oleracea L. var. capitata [L.] DC.) (Photo credit: Beniamino Leoni)

\subsection{Case Study}

Until a few years ago, a multicolored landrace of Daucus carota L., known locally as yellow-purple Polignano carrot (PC) (Figure 14) was at high risk of genetic erosion. Therefore, under the BiodiverSO project, several tasks were performed within each of the eight project activities with the aim of verifying the effectiveness of these actions in terms of safeguarding this genetic resource strongly linked with local traditions.

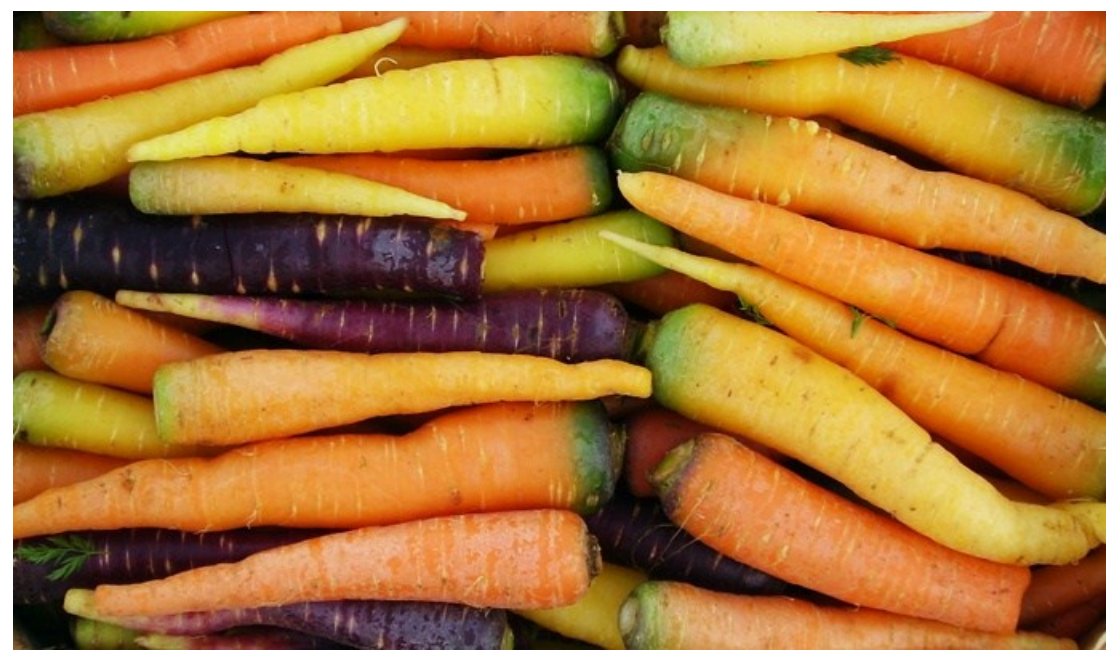

Figure 14. Polignano carrots ready for market: it is interesting to note the great variety of the root colors. 
Following bibliographic and territorial investigations (WP 1), documentary evidence supports that the PC has been cultivated for decades by local smallholder farmers in Southern Italy [17] around the town of Polignano a Mare, which is located in the southern part of the metropolitan area of Bari $\left(41^{\circ} 0^{\prime} 0^{\prime \prime} \mathrm{N} 17^{\circ} 13^{\prime} 0^{\prime \prime} \mathrm{E}\right)$. The presence of carrots in Italy is established about the end of thirteenth or the beginning of the fourteenth century, probably from Arab countries through Venice, since it had an important trade with the Middle-East countries at that time [37]. Moreover, the presence of the carrot cultivation in Puglia is established at least since 1736 [18], while to the best of our knowledge it is possible to establish the cultivation of the PC at least since 1940 [17]. Thanks to this activity, several knowledge and traditions related to the crop cycle of PC were retrieved and shared using social media (https://www.youtube.com/watch?v=S_fYKNnkkE4). The "seed" (it is an achene actually) used for planting is produced every year by the smallholder farmers. In late summer, from mid-August to mid-September, sowing is performed by a mechanical seeder placing each seed at a depth of $2-3 \mathrm{~cm}$, about $2-3 \mathrm{~cm}$ apart with a distance of $30 \mathrm{~cm}$ between rows, resulting in a seeding density of $90-120$ plants $\mathrm{m}^{-2}$ [19]. Soil fertility remaining from the previous crop is sufficient to satisfy the needs of the PC, so the PC requires no fertilization. Because of the proximity of the fields to the coast, irrigation water, extracted from underground wells (at a depth of 15-20 m), is typically brackish with electrical conductivity (EC) ranging from 3 to $4 \mathrm{dS} \mathrm{m}^{-1}$ [17]. The relatively high EC of the irrigation water is probably the main factor positively affecting carrot flavor. Harvesting normally starts in mid-December and lasts until April-May, and is performed manually using a pitchfork and is probably the most difficult step in the cultivation of this landrace [17].

Seeds of PC (Figure 15) were recovered (WP 2) to be used for ex situ conservation (WP 3) through long-time seeds preservation in seed banks as well as by in vitro techniques (Figure 16). In addition, a catalog field was realized by using soilless systems within the greenhouse (Figure 17) of the "La Noria" experimental farm - National Research Council, Bari, Italy.

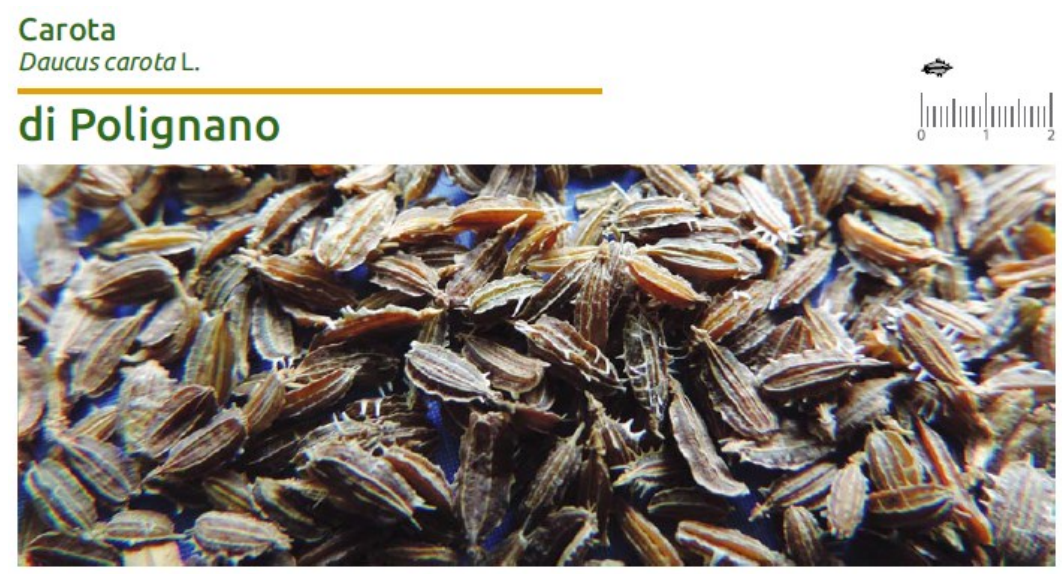

Figure 15. Seeds of Polignano carrot with indication of size (Photo credit: Beniamino Leoni). 


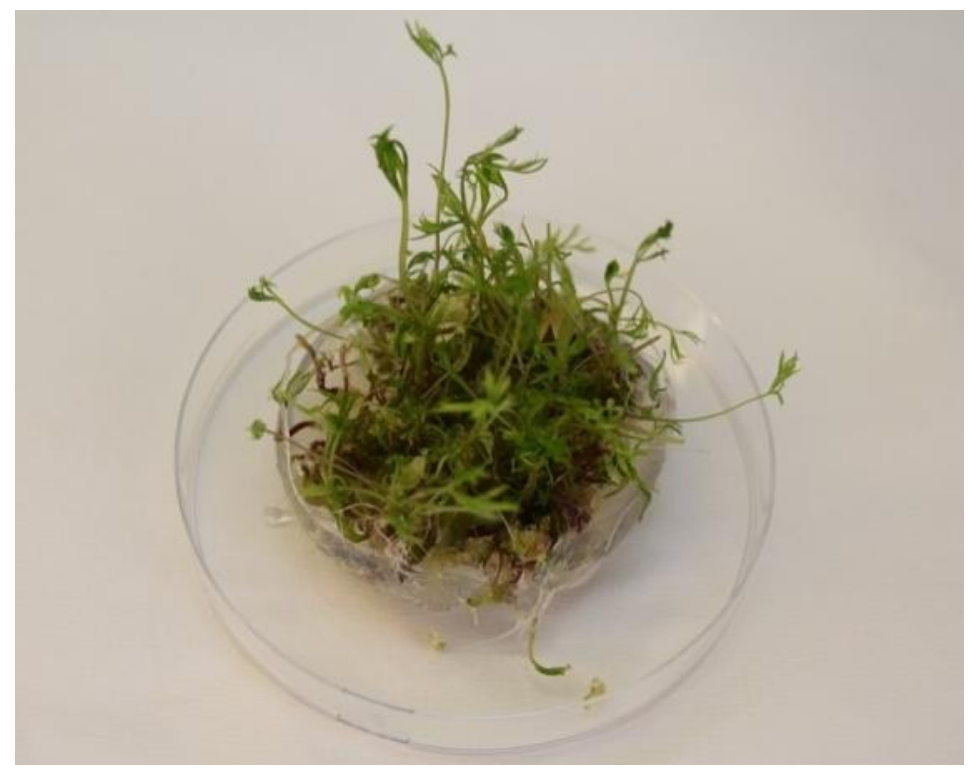

Figure 16. Seedlings of Polignano carrot obtained by micropropagation (Photo credit: Claudia Ruta-from https:/ / biodiversitapuglia.it).

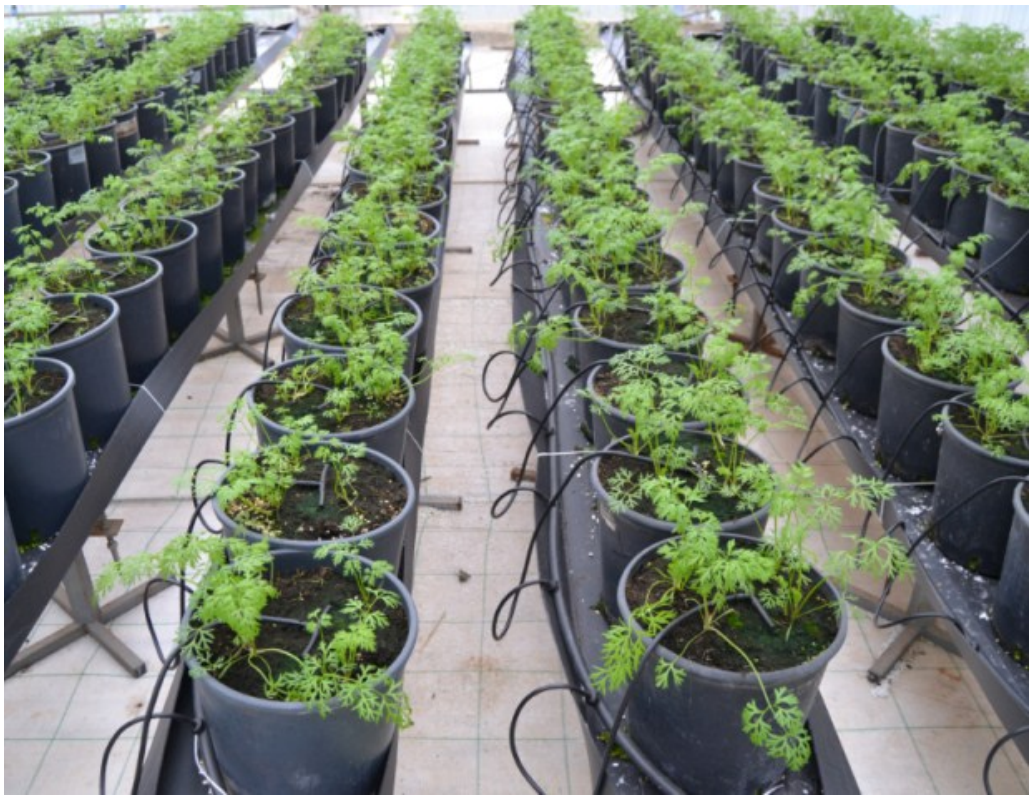

Figure 17. Catalog field of Polignano carrot realized by using soilless systems within the greenhouse of the "La Noria" experimental farm—National Research Council, Bari, Italy.

As regards characterization (WP 4), PC showed a total glucose, fructose and sucrose content (on average $4.38 \mathrm{~g} / 100 \mathrm{~g} \mathrm{FW}$ ) about $22 \%$ lower than orange commercial varieties [17]. On the other hand, this landrace showed a relative sweetness similar to some commercial carrots [17], because the highest contributor to the relative sweetness in the PC is fructose $(43.5 \%)$ which contributes to its distinctive flavor as well as to its glycemic index [17]. The roots of the PC have various skin colors which allow them to be separated into three groups: yellow, orange and purple. The purple form of PC showed an antioxidant activity (on average $42.7 \mathrm{mg}$ of Trolox equivalent/100 g FW) about tenfold higher than yellow and orange types [17]. Likewise, the total amount of phenolics in the purple PC (67.6 mg/100 g FW, on average) was fourfold higher than in yellow and orange types [17]. 
Regarding the content of total carotenoid, the purple type of PC showed an amount (on average $43.3 \mathrm{mg} / 100 \mathrm{~g} \mathrm{FW}$ ) 5.6- and 4.7-fold higher than yellow and orange types, respectively, while the $\beta$-carotene content in the purple type (on average $15.5 \mathrm{mg} / 100 \mathrm{~g} \mathrm{FW}$ ) was 3.5- and 5.9-fold higher compared to yellow and orange PC, respectively. Following physiological analysis, a drawback showed by this landrace is the short shelf-life of the roots, even at low temperatures, because of its high respiration rate; its roots are therefore considered perishable and difficult to store as a fresh product [38].

Thanks to the information obtained by WP 1 activity, in 2015, the PC was registered (WP 5) in the LTAFP of the Italian Department for Agriculture since it was demonstrated that its cultivation and processing are consolidated in time and harmonious according to traditional rules at least from 25 years.

Sharing and dissemination of the many collected information on database regarding PC (WP 6) was promoted also through Web 2.0 tools. A Wikipedia page about the PC was created from scratch (http://wiki.biodiversitapuglia.it/Carota_di_Polignano), receiving more than 15,000 page views in less than two years [25]. Moreover, a descriptive sheet was also realized and shared for users (https://biodiversitapuglia.it/varieta-orticole/carota-di-polignano/).

Finally, the in situ conservation (WP 8) is realized by pensioners (60-75 years old) who act as seed savers (Figure 18) on very small areas. For this reason, no farmer has applied for agri-environmental funding under Puglia RDP. Such an omission puts this ancient local variety at potential higher risk of genetic erosion in comparison with other genetic resources. To face this risk, smallholder farmers consumers and processors of this landrace have created the association "La bastinaca di San Vito", and have added it to the Slow Food Presidia of traditional products. In this regard, the Presidia seek to promote sustainable farming systems and, in particular, the protection of the local varieties at risk of genetic erosion as well as local traditions. The Slow Food Presidia is a project that aims to protect a community of farmers and promote their artisan food products. In this way, it is possible to stimulate market opportunities and valorize a territory through the use of a model of sustainable and environmentally friendly agriculture. At the same time, local traditions and cultural identity of people are also preserved and promoted [39].

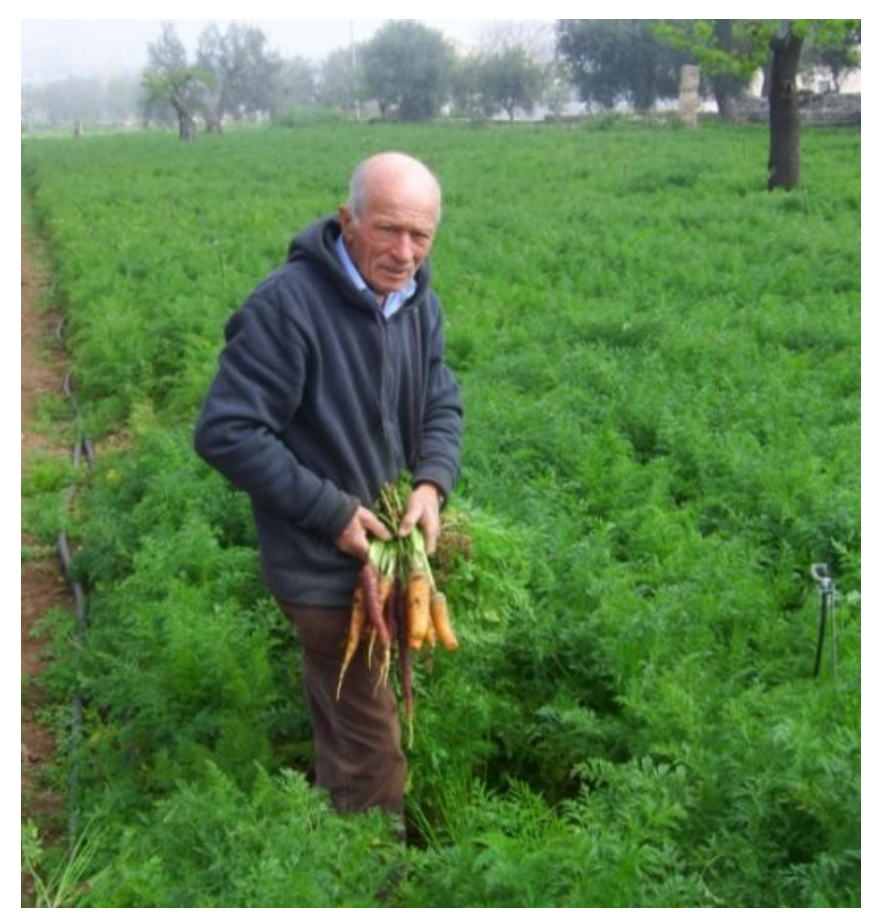

Figure 18. A local old seed savers (Oronzo Giuliacci) of the Polignano carrot. 


\section{Conclusions}

The Puglia RDP is an example of protection and recovery of vegetables at risk of genetic erosion, and its implementation through integrated projects such as BiodiverSO could help to identify and valorize much of these plant germplasms. Nevertheless, the financial support to seed savers for realizing the in situ conservation is too limited if aimed to provide an adequate incentive for cultivation. Therefore, it is important to highlight that in situ conservation of genetic resources needs to be based not only on institutional programs, but mainly on the possibility, especially for young growers, to use these resources for productive activities which would imply a real income. Moreover, the potential strategy of integrating institutional programs with research and development projects, could be a model useful to preserve the biodiversity of vegetable crops.

Author Contributions: Conceptualization, M.R. and P.S.; Methodology, M.R. and P.S.; Investigation, M.R., A.S., M.G. and P.S.; Writing-Original Draft Preparation, M.R., F.M. and P.S.; Writing-Review and Editing, M.R., F.M., A.S., M.G. and P.S.; Supervision, M.R. and P.S.; Project Administration, P.S.; and Funding Acquisition, P.S.

Funding: This research was funded by Regione Puglia Administration under Rural Development Program 2014-2020-Project "Biodiversity of vegetable crops in Puglia (BiodiverSO)", Measure 10, Sub measure 10.2, Operation 1 "Program for the conservation and the valorization of the genetic resources in agriculture".

Acknowledgments: The authors thank Beniamino Leoni for Figures 3, 5, 13 and 15 and Claudia Ruta for Figures 6 and 16.

Conflicts of Interest: The authors declare no conflict of interest.

\section{References}

1. Attitudes of Europeans towards Biodiversity. Available online: http:/ / ec.europa.eu/COMMFrontOffice/ publicopinion/index.cfm/Survey/index\#p=1\&search=biodiversity (accessed on 4 June 2018).

2. FAO. What is agrobiodiversity? In Building on Gender, Agrobiodiversity and Local Knowledge; FAO: Rome, Italy, 2004; pp. 1-18.

3. Silva, J. Biodiversity and vegetable breeding in the light of developments in intellectual property rights. Ecosystems Biodiversity; In Tech: Rijeka, Croatia, 2011; pp. 389-428.

4. Elia, A.; Santamaria, P. Biodiversity in vegetable crops, a heritage to save: The case of Puglia region. Ital. J. Agron. 2013, 8, 4. [CrossRef]

5. Zeven, A.C. Landraces: A review of definitions and classifications. Euphytica 1998, 104, 127-139. [CrossRef]

6. ISTAT. Electronic Information System on Agriculture and Livestock. Available online: http://agri.istat.it/ (accessed on 4 June 2018).

7. Bio in Cifre. Available online: http://www.sinab.it/sites/default/files/share/OK\%21\%21.pdf (accessed on 4 June 2018).

8. Hammer, K.; Laghetti, G. Genetic erosion-Examples from Italy1,2. Genet. Resour. Crop Evol. 2005, 52, 629-634. [CrossRef]

9. Laghetti, G.; Fiorentino, G.; Hammer, K.; Pignone, D. On the trail of the last autochthonous Italian einkorn (Triticum monococcum L.) and emmer (Triticum dicoccon Schrank) populations: a mission impossible? Genet. Resour. Crop Evol. 2009, 56, 1163-1170. [CrossRef]

10. Egidi, P. La Colonia Saracena Di Lucera E La Sua Distruzione; PopCorn Press: Lucera, Italy, 1915.

11. Accogli, R.; Conversa, G.; Ricciardi, L.; Sonnante, G.; Santamaria, P. Nuovo Almanacco BiodiverSO; Università degli Studi di Bari Aldo Moro: Bari, Italy, 2018; ISBN 978-88-6629-024-7.

12. Pavan, S.; Marcotrigiano, A.R.; Ciani, E.; Mazzeo, R.; Zonno, V.; Ruggieri, V.; Lotti, C.; Ricciardi, L. Genotyping-by-sequencing of a melon (Cucumis melo L.) germplasm collection from a secondary center of diversity highlights patterns of genetic variation and genomic features of different gene pools. BMC Genom. 2017, 18, 59. [CrossRef] [PubMed]

13. Ruta, C.; Lambardi, M. La coltura in vitro per la conservazione della biodiversità orticola. Italus Hortus 2018, $25,53-74$.

14. Spanò, R.; Bottalico, G.; Corrado, A.; Campanale, A.; Di Franco, A.; Mascia, T. A protocol for producing virus-free artichoke genetic resources for conservation, breeding, and production. Agriculture 2018, 8, 36. [CrossRef] 
15. Curci, P.L.; De Paola, D.; Danzi, D.; Vendramin, G.G.; Sonnante, G. Complete chloroplast genome of the multifunctional crop globe artichoke and comparison with other asteraceae. PLoS ONE 2015, 10, e0120589. [CrossRef] [PubMed]

16. Renna, M.; Signore, A.; Paradiso, V.M.; Santamaria, P. Faba greens, globe artichoke's offshoots, crenate broomrape and summer squash greens: unconventional vegetables of puglia (southern italy) with good quality traits. Front. Plant Sci. 2018, 9, 1-13. [CrossRef] [PubMed]

17. Cefola, M.; Pace, B.; Renna, M.; Santamaria, P.; Signore, A.; Serio, F. Compositional analysis and antioxidant profile of yellow, orange and purple Polignano carrots. Ital. J. Food Sci. 2012, 24, 284-291.

18. Cefola, M.; Mariani, R.; Pace, B.; Renna, M.; Santamaria, P.; Serio, F.; Signore, A. La carota di Polignano. In La biodiversità delle colture pugliesi; INEA: Bari, Italy, 2013; pp. 60-73.

19. Renna, M.; Serio, F.; Signore, A.; Santamaria, P. The yellow-purple Polignano carrot (Daucus carota L.): A multicoloured landrace from the Puglia region (Southern Italy) at risk of genetic erosion. Genet. Resour. Crop Evol. 2014, 61, 1611-1619. [CrossRef]

20. Signore, A.; Renna, M.; D'Imperio, M.; Serio, F.; Santamaria, P. Preliminary evidences of biofortification with iodine of "carota di polignano," an italian carrot landrace. Front. Plant Sci. 2018, 9, 1-8. [CrossRef] [PubMed]

21. Scarano, A.; Gerardi, C.; D'Amico, L.; Accogli, R.; Santino, A. Phytochemical analysis and antioxidant properties in colored tiggiano carrots. Agriculture 2018, 8, 102. [CrossRef]

22. Renna, M.; Gonnella, M.; Giannino, D.; Santamaria, P. Quality evaluation of cook-chilled chicory stems (Cichorium intybus L., Catalogna group) by conventional and sous vide cooking methods. J. Sci. Food Agric. 2014, 94, 656-665. [CrossRef] [PubMed]

23. Testone, G.; Mele, G.; Di Giacomo, E.; Gonnella, M.; Renna, M.; Tenore, G.C.; Nicolodi, C.; Frugis, G.; Iannelli, M.A.; Arnesi, G.; et al. Insights into the sesquiterpenoid pathway by metabolic profiling and de novo transcriptome assembly of stem-chicory (Cichorium intybus Cultigroup "Catalogna"). Front. Plant Sci. 2016, 7, 1676. [CrossRef] [PubMed]

24. Girelli, C.R.; Accogli, R.; Del Coco, L.; Angilè, F.; De Bellis, L.; Fanizzi, F.P. ${ }^{1}$ H-NMR-based metabolomic profiles of different sweet melon (Cucumis melo L.) Salento varieties: Analysis and comparison. Food Res. Int. 2018, 114, 81-89. [CrossRef]

25. Spanò, R.; Gallitelli, D.; Mascia, T. Grafting to manage infections of top stunting and necrogenic strains of cucumber mosaic virus in tomato. Ann. Appl. Biol. 2017, 171, 393-404. [CrossRef]

26. D'Acunzo, F.; Giannino, D.; Longo, V.; Ciardi, M.; Testone, G.; Mele, G.; Nicolodi, C.; Gonnella, M.; Renna, M.; Arnesi, G.; Schiappa, A.; Ursini, O. Influence of cultivation sites on sterol, nitrate, total phenolic contents and antioxidant activity in endive and stem chicory edible products. Int. J. Food Sci. Nutr. 2017, 68, 52-64. [CrossRef] [PubMed]

27. Renna, M.; Cocozza, C.; Gonnella, M.; Abdelrahman, H.; Santamaria, P. Elemental characterization of wild edible plants from countryside and urban areas. Food Chem. 2015, 177, 29-36. [CrossRef] [PubMed]

28. Renna, M.; Rinaldi, V.A.; Gonnella, M. The Mediterranean Diet between traditional foods and human health: The culinary example of Puglia (Southern Italy). Int. J. Gastron. Food Sci. 2015, 2, 63-71. [CrossRef]

29. Renna, M. Wild edible plants as a source of mineral elements in the daily diet. Prog. Nutr. 2017, 19, $219-222$.

30. Renna, M.; Serio, F.; Santamaria, P. Crenate broomrape (Orobanche crenata Forskal): prospects as a food product for human nutrition. Genet. Resour. Crop Evol. 2015, 62, 795-802. [CrossRef]

31. Renna, M.; Gonnella, M. The use of the sea fennel as a new spice-colorant in culinary preparations. Int. J. Gastron. Food Sci. 2012, 1, 111-115. [CrossRef]

32. Renna, M.; Gonnella, M.; Caretto, S.; Mita, G.; Serio, F. Sea fennel (Crithmum maritimum L.): from underutilized crop to new dried product for food use. Genet. Resour. Crop Evol. 2017, 64, 205-216. [CrossRef]

33. Giungato, P.; Renna, M.; Rana, R.; Licen, S.; Barbieri, P. Characterization of dried and freeze-dried sea fennel (Crithmum maritimum L.) samples with headspace gas-chromatography/mass spectrometry and evaluation of an electronic nose discrimination potential. Food Res. Int. 2018, in press. [CrossRef]

34. Montesano, F.F.; Gattullo, C.E.; Parente, A.; Terzano, R.; Renna, M. Cultivation of potted sea fennel, an emerging mediterranean halophyte, using a renewable seaweed-based material as a peat substitute. Agriculture 2018, 8, 96. [CrossRef]

35. Signore, A. Mapping and sharing agro-biodiversity using Open Data Kit and Google Fusion Tables. Comput. Electron. Agric. 2016, 127, 87-91. [CrossRef] 
36. Signore, A.; Serio, F.; Santamaria, P. Wikipedia as a tool for disseminating knowledge of (agro)biodiversity. Horttechnology 2014, 24, 118-126.

37. Banga, O. The development of the original European carrot material. Euphytica 1957, 6, 64-76. [CrossRef]

38. Renna, M.; Pace, B.; Cefola, M.; Santamaria, P.; Serio, F.; Gonnella, M. Comparison of two jam making methods to preserve the quality of colored carrots. LWT-Food Sci. Technol. 2013, 53, 547-554. [CrossRef]

39. Renna, M. From the farm to the plate: Agro-biodiversity valorization as a tool for promoting a sustainable diet. Prog. Nutr. 2015, 17, 77-80.

(C) 2018 by the authors. Licensee MDPI, Basel, Switzerland. This article is an open access article distributed under the terms and conditions of the Creative Commons Attribution (CC BY) license (http:/ / creativecommons.org/licenses/by/4.0/). 